\title{
The Application of Class Games in English Teaching
}

\author{
Weiwei Zou \\ Nanchang Institute of Science \&Technology, Nanchang 330108,China
}

Keywords: Class Games; English Teaching; Strategy

\begin{abstract}
This paper mainly discusses the application of this special classroom teaching in vocational English teaching. This paper puts forward several common teaching games, and gives the corresponding examples, from which summed up in the design of class games should master the strategy.
\end{abstract}

\section{Introduction}

In recent years, communicative English teaching and task-based teaching have been widely recognized and applied in English teaching.As a part of vocational education, the importance of English communicative competence is particularly prominent in the whole English teaching.English classroom should not rigidly adhere to the traditional teaching of teaching methods, but should be a lively and open classroom, a dynamic new classroom.Game in English teaching plays a role that can not be ignored, if teachers can use the game in a timely manner, not only to improve student interest in learning, but also to achieve a multiplier effect of teaching.English learning is boring, in order to enhance the enthusiasm of students to improve the classroom effect, happy teaching is a useful attempt in English teaching interspersed with a significant effect of the game.

The current college English teaching is also constantly reforming,college English teaching goal is to develop students' comprehensive application ability, especially listening and speaking ability.Teaching model should reflect the practicality of English teaching, knowledge and fun of the principle of combining the two aspects, should fully mobilize the enthusiasm of teachers and students, in particular,and establish students in the teaching process of the dominant position.Interesting can not be ignored, it is to improve the knowledge and practicality of college English teaching an indispensable auxiliary means and catalyst.To increase the interest of classroom teaching, I believe that you can start from the classroom game. Although people think that the game is things a child to do . But they ignore the point:Even adults do not exclude games.Games can also be used in university classes, the key is to see what teachers and students can get from the game.In this paper, from the perspective of interest theory, the paper introduces the feasibility of college English classroom games.

\section{The Benefits of Class Games}

Teaching games can exclude the psychological pressure of students to learn the language. The fun of the game itself active classroom atmosphere, the tension and monotonous learning has become relaxed and happy. When students are in this relatively relaxed and lively atmosphere, it is easier to overcome the language learning anxiety.We know that adults learn foreign language the biggest psychological barrier is the lack of confidence and courage, fear of making mistakes, afraid of losing face, and the game can make people free, in the game, all shyness will disappear, the students will feel relaxed, attention is attracted by the fun of the game, in the unknowingly learned 
the target language.

Teaching games can better help students acquire language. The richness of the game can bring students' interest and play their imagination, and many games require them to be dedicated.In this case, the students will be more impressed by the materials learned, remember firmly, so that teaching better results.Psycho-linguistic tests have shown that interesting forms or contents can increase memory by a factor of 1.5.In addition, class games teachers innovate in the classroom,and students will have a sense of expectation and freshness, which can stimulate their enthusiasm for learning, so that they tire of learning.

Teaching games can explore a wide range of potential students. In the game, students must make full use of their understanding, analysis, judgment, imagination, logical reasoning ability,but also requires them to respond agile, witty and flexible and creative.

\section{The Choice and Design of Game Form}

The form of the game should take into account the number of students, English proficiency, cultural scene, time control, learning themes and classroom scenes and other factors, attention and teaching materials.During the activity, the teacher should unequivocally tell the student how to carry on the activity, guaranteed that each student can participate in the language practice.Special attention should also be given to those students who are easily tense and inactive, encouraging them to speak English and patiently answering the difficult questions posed by the students.It should be noted that teachers should also change the team members often, so as to avoid too much understanding between the students and make the topic boring, without any controversy will be able to reach an agreement.In the process of organizing activities should also pay attention to from easy to difficult, step by step, the lifting of students of tension, eliminate psychological barriers, improve students' interest in the activities.We divided the language practice into listening, speaking, reading, writing four kinds of skills, classroom games can exercise the skills of English. Here are the activities you can expand on these four skills:

Listening Games. Listening is the process of understanding the language.In the specific operation of the teaching process, it is very important how to use the communicative principle of language to establish the psychological mechanism of students' communication with listening materials.Teachers prepare students to practice the content which should be designed to mostly daily life, so that students have a sense of participation.

EG. "Listen and Say" Game

1)Prepare a few sentences related to learning content

2)Divide the students into groups and stand in line.

3)The first student of every group comes to find the teacher , listening to the teacher whispered sentence,after listening clearly, quickly ran back to the second student, the last one say the sentences he heard loudly. Which group is exactly the winner.

4)The purpose of this activity is to train students' listening and speaking ability.

In the classroom teaching can also be simple strokes and combine with hearing.The teacher first introduces students to possible vocabulary in the listening practice, and then describes a picture by the teacher or by modern means such as a tape recorder. Each student is required to draw an image on the paper according to the content he hears. Teachers can also invite students to paint on the blackboard.The design of the game should be appropriate for the students' language and vocabulary.If it is too difficult, students will feel frustrated; if too easy, can not achieve effective training.Games that make students relax and feel interesting make it easier for them to learn and remember new vocabulary so they can participate actively in the learning process. 
Speaking Games. Oral language is the process of verbal thought. What the teacher has to do is to promote the participation of all the students.

\section{EG. Guessing}

1)Prepare a large number of cards, each card is painted with an article or animal.

2)Let one of the students stand in front of other people,others can use some questions to ask the students.eg. Does it eat grass? Does it live in the water? Answer it with YES or NO.

3)Students can guess what information they can get from the $\mathrm{Q} \& \mathrm{~A}$

Test what exactly is drawn on the card? Who guess is the winner. Story Solitaire game

The teacher gives student the beginning and then asks the student to repeat everything he heard in front of him. He continues the story by asking the story-line to be logical, and the final classmates will finish the story.Eg. I was ill yesterday. The first student should say:I was ill yesterday.I went to the hospital.The second student still had to repeat all of the sentences in front of it and let the story develop, and the last student had to give the story a happy ending.

This form of the game is more free, the classroom atmosphere is more intense, more students play a rich imagination, the final outcome of the story is often surprising and very exciting.

Reading and Performing Games. Reading is the main source of language input and accumulation.In the long run, a large number of reading is to expand the vocabulary of the fundamental way to read a lot of catchy, authentic English reading materials or books, is to improve the spoken language one of the fundamental way.Teachers can choose a period of literary works of the classic dialogue, printed after the students asked to read and memorize in mind, and then divided into two or more groups to perform a role.According to classroom practice, I found that most students put aside shy, completely into the feelings of the hero, performance seriously.Excellent literary works rich in content, beautiful language.Through the characters, events and plot in the literary works, students can understand the target language culture more deeply.And such activities to the students' performance can provide a platform for display, and achieved good teaching results.

Writing Games. Writing is a language practice that can not be ignored.Writing not only helps to consolidate language materials that are input through reading and writing, to promote the internalization of language knowledge, to improve the accuracy of language use, but also to lay a solid foundation for substantive oral proficiency.But writing has always been one of the difficulties in teaching.Students often feel boring.In addition to teaching students to the presentation format, paragraph writing, genre, rhetoric and other knowledge, but also should improve the interest of students writing.For example, the teacher writes the name of the whole class on a piece of paper and makes sure that each student gets the name on his or her note,

And then asked the students s to describe the person's character characteristics or memory of the students the most profound impression of a thingin100 word according to their understanding, , etc.And then read separately, by the class to guess who is described.

Games can also take many forms.For example,hot topic debate, interviews, competition, speculation and so on.In fact the game training is not just a skill.English proficiency is a comprehensive reflection of skills in a variety of languages, these skills complement each other and promote each other.

\section{Seeking efficiency, give a timely manner feedback according to the game results}

Feedback is an important means of control of the game, teachers in the game activities should be static and dynamic observation of the combination, at any time access to the feedback 
Teachers should be good at the specific circumstances of student feedback. At any time to amend the objectives of this game, flexible control of the game time and manner, a good grasp of the "furnace". Truly feedback "timely" and "inspiring” and "incentive”.

In the course of the game, teachers through observation, questioning, inspections, etc. to understand the students learning, especially students learning attitude, learning aspirations and learning results, according to the students learning feedback, Arrangements to take timely adjustment, flexible control, and should not be subject to the original game design restrictions.

After the game, the results of feedback, reflection to improve. Most games have evaluation means, the game is over, the teacher to the results of their feedback to the students, at any time to evaluate and recognize the progress of students to encourage students to develop. And students to discuss the game activities in the shortcomings and improvements, together with the establishment of goals, to encourage students to work towards the goal.

Teachers also have to this game is to achieve the teaching objectives, the students participate in the process of the game have a positive emotional attitude, whether there is a good learning effect to reflect on improvement. In order to look forward to the next game activities more effective.

\section{Conclusion}

The active participation of learners is a very important part in English teaching. Teachers should strive to create a language environment for students and opportunities for students to provide practical communication with the significance of the activities to stimulate their exchange of ideas.Classroom games are highly communicative language practice activities, which meet the students' lively, curious, good at imitating and like the psychological characteristics of communication, but also to adapt to the needs of English teaching.

\section{Acknowledgment}

This research was financially supported by the Jiangxi Province Education Reform Foundation.

Project Name:Practice and Application of VESL Teaching Mode in Applied Technological Undergraduate College

Project Number: JXJG-15-27-5

\section{References}

[1] Xue-mei WANG, The Design of English Class Students' Game Activities [J],Journal of Liaoning Teachers College,2005,3

[2] Dian-yu WU, Foreign English classroom teaching methods[J], ,Journal of Wuzhou Teachers College,1997,1

[3] Shun-feng HU, Introduce classroom games [J], Hunan Education, 1999,10

[4] Lee Su Kim. Creative Games for the Language Class[J]. Forum. V01. 33. 1995, (1): 35-38.

[5]Ellis,R.Classroom second Language Development[M] London: Practice Hall International (UK) Ltd. 1998. 